\title{
Tratamiento de fractura del tercio medio facial mediante la técnica de 'midfacial deglobing'. Reporte de un caso
}

\section{Treatment of midfacial fracture by midfacial degloving. Case report}

\author{
A.R. Méndez Tenorio', I. Sahagun Pille²
}

\begin{abstract}
Resumen: Tradicionalmente, el abordaje quirúrgico hacia las estructuras del tercio medio de la cara en trauma maxilofacial ha sido a través de incisiones intraorales sublabiales y de incisiones cutáneas10. La técnica de disección del tercio medio facial ha sido desarrollada con el uso combinado de incisiones sublabiales y de rinoplastia por Casson, quien en 1974 describe la técnica para tener acceso a esta zona en el tratamiento de lesiones neoplásicas sinonasales superficiales. Existen pocos reportes en la literatura referente a su uso en trauma facial. En este artículo se reporta la aplicación de esta técnica como abordaje estético para fracturas del tercio medio facial. Los resultados obtenidos en este caso coinciden con los reportados en la literatura y demuestran que la técnica presenta diversas ventajas ante los abordajes convencionales, ya que proporciona un amplio campo visual a la zona quirúrgica, evita el uso de incisiones cutáneas con sus secuelas estéticas cursando con un postoperatorio satisfactorio. Como conclusión, de acuerdo con los resultados obtenidos en el caso, la técnica de disección de tercio medio facial fue aplicable y segura como abordaje quirúrgico en trauma facial, y presenta diversas ventajas que la favorecen al planear el abordaje quirúrgico a utilizar.
\end{abstract}

Palabras clave: Fracturas del tercio medio facial; Abordajes quirúrgicos; Disección del tercio medio facial.

Recibido: 16.06 .2008

Aceptado: 15.10 .2008

\begin{abstract}
Surgical access to midface structures in maxillofacial trauma traditionally has been obtained by sublabial incisions and cutaneous incisions for orbital trauma (subciliary, infraorbital, Lynch, "H" or "open-sky" and gull-wing incisions). The midfacial degloving procedure was developed by associating sublabial incisions with rhinoplasty incisions and used to gain access to and treat superficial sinonasal neoplasms, according to a report by Casson in 1974. There have been a few reports of the use of this procedure in facial trauma. We used this technique as a internal approach for a patient with panfacial fractures. The technique demonstrated several advantages over conventional techniques for approaching the midfacial bones. It provided an extended surgical field, eliminated cutaneous incisions and their esthetic sequelae, and had a complication-free postoperative course. Our results showed that the midfacial degloving procedure is a useful and safe technique for securing access in facial trauma.
\end{abstract}

Key words: Midfacial fractures; Surgical access; Midfacial degloving procedur.
1. Cirujano Oral y Maxilofacial.

Práctica privada. Ciudad de México.

2 Médico adscrito al Servicio de Cirugía Maxilofacial

Hospital de Traumatología Victorio de la Fuente Narváez IMSS. Ciudad de México. México

\section{Correspondencia:}

Dr. Andrés R. Méndez Tenorio

Av. Cuauhtemoc $9601^{\circ}$

México D.F. C.P. 03020

E-mail: a.mendez@gnathosmf.com 


\section{Introducción}

Tradicionalmente, el abordaje quirúrgico hacia las estructuras del tercio medio en trauma maxilofacial ha sido a través de incisiones sublabiales y cutáneas para lesiones orbitarias de suelo y pared medial. La técnica de disección del tercio medio facial ha sido desarrollada con el uso combinado de incisiones sublabiales y de rinoplastia, para tener acceso a esta zona en el tratamiento de lesiones neoplásicas sinonasales superficiales. En 1974, Casson propone el procedimiento como abordaje al esqueleto del tercio medio facial por diferentes indicaciones como fracturas faciales, resecciones de tumores en el maxilar, osteotomias del tercio medio o en procedimientos que requieran de injertos óseos. ${ }^{1}$ Diversos autores popularizaron su uso como Mangiglia, ${ }^{2}$ Hollyday ${ }^{3}$ y Romo,${ }^{4}$ siendo aplicado principalmente en cirugía de cabeza y cuello como abordaje para la resección de neoplasias de senos paranasales benignos y malignos. El primer reporte de su aplicación como abordaje quirúrgico en trauma facial es con Baumann y Ewers, ${ }^{5}$ quienes lo aplicaron en 14 pacientes con fracturas del tercio medio facial.

Esta técnica permite exposición de las estructuras del tercio medio facial sin incisiones cutáneas externas. El procedimiento de disección del tercio medio facial requiere de habilidad tanto en cirugía de senos paranasales como de rinoplastia básica, debido a que el abordaje involucra una incisión bilateral sublabial, junto con elevación del tejido blando de todo el dorso nasal. La irrigación de la piel desinsertada es suplida por las arterias infraorbitaria y facial, por lo que se pueden realizar otras incisiones para proporcionar exposición adicional sin comprometer la vascularidad de la zona. ${ }^{3}$

\section{Indicaciones clínicas}

1. Para la resección de enfermedad sinonasal benigna, particularmente papiloma invertido, angiofibroma y enfermedad fibroósea.

2. Septodermoplastia y reparación de perforaciones septales amplias.

3. Fracturas del tercio medio facial.

4. Osteotomías del tercio medio facial.

5. Injertos óseos en el tercio medio facial para la reconstrucción del contorno facial.

6. Tumores malignos selectos que puedan ser abordados adecuadamente con la exposición conseguida, por ejemplo, angiofibroma y papiloma invertido.

El procedimiento de disección del tercio medio facial es idealmente aplicable en niños y en adolescentes, en quienes las incisiones externas pueden ser particularmente indeseables. Sin embargo, también se puede realizar en adultos.

\section{Ventajas}

1. Buena exposición de las cavidades nasales, tercio medio de la cara y base del cráneo en su porción central.

2. Permite modificación y extensión adicional.

3. No hay cicatrices externas.

\section{Introduction}

The traditional surgical approach to midfacial structures in maxillofacial trauma has been through a sublabial incision and cutaneous incisions for floor and medial wall injuries of the orbit. The midfacial degloving technique was developed using a combination of sublabial incisions and rhinoplasty to obtain access to this area to treat superficial sinonasal neoplastic lesions. In 1974, Casson proposed the procedure as an approach to the midfacial bones for indications such as facial fracture, resection of maxillary tumors, midfacial osteotomy, or bone grafts procedures. ${ }^{1}$ Various authors popularized its use, such as Mangiglia, ${ }^{2}$ Hollyday, ${ }^{3}$ and Romo, ${ }^{4}$ and it has been used mainly in head and neck surgery for the resection of benign and malignant neoplasms of the paranasal sinuses. The first report of the use of midfacial degloving as a surgical approach to facial trauma was by Baumann and Ewers, 5 who used it in 14 patients with midfacial fractures.

This technique allows midfacial structures to be exposed without using external skin incisions. The midfacial degloving procedure requires skill in both paranasal sinus surgery and basic rhinoplasty because the approach involves a bilateral sublabial incision and raising the soft tissues of the dorsal nose. The irrigation of the deinserted skin is supplied by the infraorbital and facial arteries, so other incisions can be made to enhance exposure without compromising the vascularization of the area. ${ }^{3}$

\section{Clinical indications}

1. Resection of benign sinonasal processes, particularly inverted papilloma, angiofibroma, and fibro-osseous disease

2. Septodermoplasty and repair of large septal perforations

3. Midfacial fractures

4. Midfacial osteotomy

5. Midfacial bone grafts for reconstruction of the facial contour

6. Certain malignant tumors that can be approached properly using this exposure, e.g., angiofibroma and inverted papilloma.

The midfacial degloving procedure is ideal for children and adolescents, in which external incisions can be particularly undesirable. It also can be performed in adults.

\section{Advantages}

1. Good exposure of the nasal cavities, midface, and central skull base is obtained.

2. It allows additional modification and extension

3. There are no external scars

4. Postoperative complications are minimal.

5. A wide variety of diseases can be controlled successfully.

6. Patient tolerance is good. 
4. Complicaciones postoperatorias mínimas.

5. Control exitoso de una amplia variedad de enfermedades.

6. Buena tolerancia del paciente.

\section{Desventaja}

La única desventaja es la incidencia ocasional de estenosis del vestíbulo nasal.

\section{Técnica quirúrgica}

Se advierte al paciente antes del procedimiento sobre el trauma quirúrgico y edema facial resultante, así como la posibilidad de su resolución con el tiempo. También, se comenta sobre la formación de costras intranasales, particularmente en aquellos pacientes que se someten a retiro de las lesiones más extensas. También se previene al paciente en relación a la parestesia que puede experimentar después de la operación.

La operación se realiza bajo anestesia general; el tubo endotraqueal se coloca centralmente en la boca y se fija al mentón. El paciente se coloca en posición supina en Trendelenburg invertido con una flexión de la cabeza hacia arriba de aproximadamente $15^{\circ}$. Se infiltra xylocaina con adrenalina 1:200.000 en los sitios de incisión propuestos del tejido blando de la nariz, surco bucogingival y cara anterior del maxilar, para producir hemostasia.

1. Se colocan suturas de tarsorrafia o protectores corneales de modo bilateral.

2. Se realiza una incisión sublabial bilateral con una extensión lateral hasta la tuberosidad maxilar en ambos lados (Fig. 1).

3. El periostio sobre la cara anterior del maxilar se eleva bilateralmente junto con los tejidos blandos, teniendo cuidado en identificar y preservar los nervios infraorbitarios.

4. A continuación se utilizan incisiones intercartilaginosas tipo rinoplastia (Fig. 1). Esto permite separación de los tejidos blandos de la nariz de los cartílagos laterales superiores. El periostio suprayacente a los huesos nasales se eleva tan lateral y superior como sea posible hasta la raíz de la nariz. Se usa ahora una incisión de transficción (Fig. 1) a lo largo de los bordes dorsal y caudal del septum cartilaginoso desde la prolongación medial de los cartílagos laterales inferiores. Esa incisión se extiende a lo largo del suelo de la fosa nasal hasta el aspecto lateral de la fosa piriforme conectándose con la incisión intercartilaginosa para una liberación circunvestibular completa (Fig. 1). Se completa el procedimiento con disección cortante lateralmente conectando la nariz desinsertada con las áreas anteriores del maxilar previamente disecadas.

\section{Disadvantage}

The only disadvantage is the occasional occurrence of nasal vestibule stenosis.

\section{Surgical technique}

The patient is informed before the procedure about the surgical trauma and facial edema that are involved and how it would resolve with time. Intranasal scab formation is mentioned, particularly in patients who undergo the removal of more extensive lesions. The patient is advised that paresthesia may occur after the operation.

The operation is performed under general anesthesia; an endotracheal tube is placed in the center of the mouth and affixed to the chin. The patient is placed in supine inverted Trendelenburg position with the head flexed upward about $15^{\circ}$. Xylocaine with epinephrine 1:200 000 is infiltrated in the planned incision sites of the nasal soft tissues, buccogingival sulcus, and anterior face of the maxilla to control bleeding.

1. Tarsorrhaphy sutures or corneal protectors are placed bilaterally.

2. A bilateral sublabial incision is made and extended laterally to the maxillary tuberosity on both sides (Fig. 1).

3. The periosteum on the anterior face of the maxilla is lifted bilaterally with the soft tissues, taking care to identify and preserve the infraorbital nerves.

4. Rhinoplasty type intercartilaginous incisions are then made (Fig. 1). The soft tissues of the nose are separated from the superior lateral cartilages. The periosteum overlying the nasal bones is raised laterally and superiorly as much as possible to the root of the nose. A transfixion incision is now made (Fig. 1) along the dorsal and caudad edges of the cartilaginous septum from the medial prolongation of the inferior lateral cartilages. That incision is extended along the floor of the nasal fossa to the lateral aspect of the pyriform fossa and connected with the intercartilaginous incision to completely free the circumvestibular area (Fig. 1). The procedure is completed by cutting lateral dissection to connect the deinserted nose with the previously dissected areas of the maxilla.

5. The midfacial skin is deinserted superiorly from the skull to the line of the frontonasal suture and infraorbital rim and laterally to the zygomatic process. The mouth is 
5. La piel del tercio medio de la cara se desinserta del cráneo superiormente hasta la línea de sutura frontonasal, el reborde infraorbitario y lateralmente, hasta el proceso cigomático. La boca puede ser retraída lateralmente lo suficiente para disecar por atrás del seno maxilar hacia la fosa infratemporal.

\section{Puntos especiales a observar}

A. Se requiere retracción considerable durante esta operación y se debe tener cuidado de evitar lesionar el nervio infraorbitario.

B. El aporte sanguíneo al colgajo facial se deriva de las arterias facial, infraorbitaria, supratroclear y transversa de la cara. Esta vascularidad permite la adición de incisiones nasales laterales y orbitarias mediales, que se requieren para una exposición amplia.

C. El canal, foramen y paquete vasculonervioso infraorbitario pueden ser liberados mediante osteotomias a lo largo de cada lado del canal. Se obtiene así movilidad mejorada del colgajo y un acceso incrementado a las órbitas.

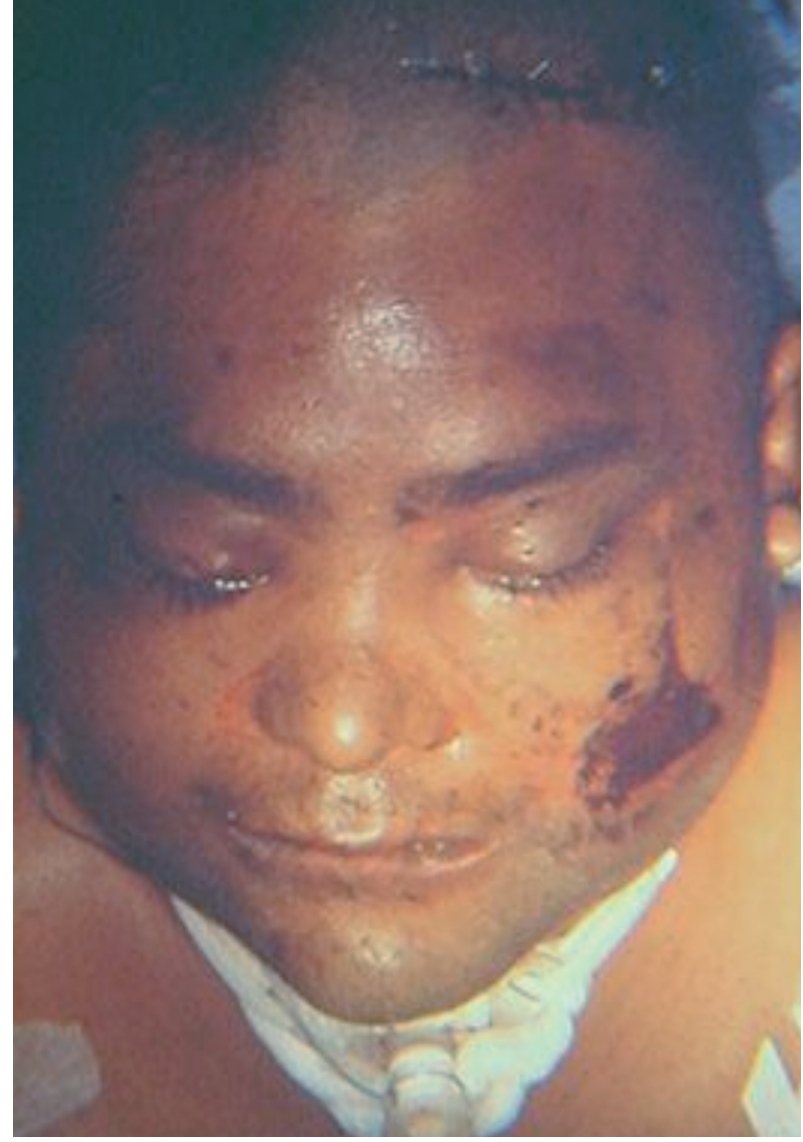

Figura 2. Vista prequirúrgica de frente. Figure 2. Frontal preoperative view. drawn far enough laterally to dissect behind the maxillary sinus to the infratemporal fossa.

\section{Special considerations}

A. Considerable retraction force is required during this operation and care should be taken to avoid injuring the infraorbital nerve.

$B$. The blood supply to the facial flap derives from the facial, infraorbital, supratrochlear, and transverse arteries of the face. This vascularization allows lateral nasal and medial orbital incisions to be added, which are required for extensive exposure.

C. The infraorbital canal, foramen, and vasculonervous package can be released by osteotomies along each side of the canal. Improved flap mobility and increased access to the orbits is achieved.

The nasal structures are nan cuidadosamente y se aplican con precisión suturas reabsorvibles, asimismo se cierran con cuidado las incisiones sublabiales. El uso de la vestidura y férula nasal ayudarán a inmovilizar la nariz, a reducir el edema facial y evitar el desarrollo de hematoma.

\section{Complicaciones}

Son raras las complicaciones notables con esta técnica, siendo la mas común estenosis del vestíbulo nasal que ocurre aproximadamente en el $5 \%$ de los pacientes.6,7 No se ha reportado alteración del crecimiento facial en niños, rinitis atrófica, epífora o fístula oroantral.

Ante la incidencia de secuelas estéticas como cicatrices visibles resultantes de los abordajes cutáneos convencionales, se aplicó la técnica de disección de tercio medio facial en un paciente con fractura panfacial, con la intención de proporcionar el tratamiento quirúrgico sin incisiones cutáneas.

\section{Caso clínico}

Se trata de un paciente varón de 41 años de edad quien inicia su padecimiento actual al sufrir accidente en su domicilio y caer repositioned carefully and resorbable sutures are made. The sublabial incisions are closed carefully. The use of nasal dressing and a splint helps to immobilize the nose, reduce facial edema, and avoid the development of hematoma.

\section{Complications}

Major complications with this technique are rare, the most common being stenosis of the nasal vestibule, which occurs in approximately $5 \%$ of patients 5,7 No disturbance in the facial growth of children, atrophic rhinitis, epiphora, or oroantral fistula has been reported.

Given the fact that conventional cutaneous approaches are disfiguring, the midfacial degloving technique was used in a patient with panfacial fracture to allow surgical treatment without skin incisions.

\section{Clinical case}

A 41-year-old male patient suffered an accident at home consisting of a fall from the third floor, from an approximate height of 10 meters, which originated multiple fractures of 
del $3^{\text {er }}$ piso, a una altura aproximada de 10 metros, resultando con fracturas múltiples en cara, fémur derecho y radio y cúbito derechos. Ingresa al servicio de terapia intensiva del Hospital de Traumatología "Victorio de la Fuente Narváez" IMSS con un índice de Glasgow 8,10 se le realiza traqueostomia de urgencia. Se le indican exámenes de laboratorio y TC de cráneo y cara para evaluar las lesiones presentes. Tras la estabilización de su vía aérea, se solicita interconsulta al servicio de cirugía maxilofacial. Se establece el diagnóstico de fractura panfacial en base a los hallazgos tomograficos con los siguientes componentes (Fig. 3):

- Fractura nasoorbitoetmoidal.

- Fractura del complejo cigomático malar izquierdo tipo 2 no desplazada y 3, así como tipo 4 del lado derecho. ${ }^{10}$

- Fractura maxilar tipo Le Fort I

- Fractura parasinfisiaria derecha

- Fractura de la rama mandibular derecha.

Se realiza fijación intermaxilar con arcos barra y tracción elástica. Ingresa al servicio de terapia intensiva por presentar desequilibrio hidroelectrolítico; se programa para reducción abierta de fracturas faciales bajo anestesia general balanceada a los 13 días de su ingreso a estancia intrahospitalaria, utilizando disección del tercio medio facial como abordaje para esta zona e incisiones transconjuntivales para acceder a ambos pisos de orbita.

Los hallazgos durante la cirugía incluyen fractura a nivel de sutura frontonasal, fractura bilateral de rebordes infraorbitarios sin afección del piso orbitario, fractura en pilares cigomáticos, fractura de pared anterior de seno maxilar y rebordes piriformes bilateral (Fig. 4). Además presentaba una fractura parasinfisiaria derecha de la mandíbula. Se realiza reducción y fijación de las fracturas con sistema Synthes 2.0 para las del tercio medio facial (Fig. 5) y las fracturas mandibulares se manejaron conservadoramente, debido a que desde la fijación intermaxilar la oclusión se restituyó de manera estable. Posterior a la cirugía, el paciente reingresa al servicio de terapia intensiva donde se mantuvo durante 5 días, cuando mejoró su estado general y pudo ingresar a piso.

En las citas de control, el paciente muestra adecuada evolución postquirúrgica, cursando con edema que se resuelve len- the face, right femur, and right radius and ulna. He was admitted to the intensive care unit of "Victorio de la Fuente Narváez" Traumatology Hospital with a Glasgow index of 8. ${ }^{10}$ Emergency tracheostomy was performed. Laboratory examinations and $\mathrm{CT}$ of the skull and face were performed to evaluate the injuries present. After airway stabilization, an opinion was requested from the maxillofacial surgery department. The panfacial fracture was diagnosed on the basis of tomographic findings and had the following components (Fig. 3):

- Nasal-orbital-ethmoidal fracture

- Type 2 and 3 fracture of the left zygomatic-malar complex without displacement and type 4 fracture of the right side. ${ }^{10}$

- Le Fort I maxillary fracture

- Right parasymphyseal fracture

- Fracture of the right mandibular ramus

Intermaxillary fixation was secured with bar arches and elastic traction. The patient was admitted to the intensive care unit for electrolyte imbalance. He was scheduled for open reduction of the facial fractures under general anesthesia 13 days after admission to the hospital. Midfacial degloving was used as an approach for this zone and transconjunctival incisions provided access to both orbital floors. The findings of surgery included fracture at the level of the frontonasal suture, bilateral fracture of the infraorbital rims without orbital floor involvement, fracture of zygomatic pillars, and fracture of the anterior wall of the maxillary sinus and bilateral pyriform rims (Fig. 4). He also had a right parasymphyseal fracture of the mandible. The fracture was reduced and immobilized with the Synthes 2.0 system for midfacial fractures (Fig. 5) and mandibular fractures were managed conservatively because occlusion was restored by intermaxillary fixation. After surgery, the patient was readmitted to the intensive care unit, where he remained for 5 days. When his general condition improved, he was transferred to the ward.

At his follow-up appointments, the patient showed an appropriate postoperative evolution, coursing with edema 
tamente, y la cicatrización de las zonas de abordaje es adecuada, sin presencia de hematoma o estenosis del vestíbulo nasal. La fijación intermaxilar se mantuvo durante 8 semanas, cursando durante este periodo de inmovilización sin complicaciones y con una oclusión estable. Después del retiro de la fijación intermaxilar se observa oclusión sin alteraciones. Las relaciones espaciales de la cara fueron restituidas después del tratamiento quirúrgico (Fig. 6). Las radiografías de control muestran las zonas fracturadas con miniplacas en posición adecuada, y confirmando que las relaciones anteroposteriores, sagitales y transversales del tercio medio de la cara se restablecieron (Fig. 7).

\section{Discusión}

Existe una amplia bibliografía en relación a las aplicaciones de la disección del tercio medio facial como abordaje quirúrgico para el tratamiento de la patología sinonasal benigna y maligna superficial. ${ }^{1-9}$

En 1992, se hace referencia a la aplicación de la técnica para trauma facial, no es sino hasta 2001 cuando Baumann y Ewers, ${ }^{5}$ reportan por vez primera en la literatura maxilofacial su experiencia en el uso de la técnica con 14 pacientes de trauma de tercio medio facial, obteniendo buenos resultados tanto en exposición del campo quirúrgico como en la disminución de complicaciones postoperatorias como las que se habían reportado previamente en la literatura.

En este artículo, se reporta un caso de trauma facial severo manejado con la técnica de disección del tercio medio facial como abordaje para esa zona, donde se observó que de acuerdo con los resultados observados en el caso la técnica en efecto es aplicable y segura, y que el curso postoperatorio resultó sin eventualidades. Los resultados de su aplicación en este estudio se semejan con aquellos reportados en la literatura, confirmando que se trata de una técnica quirúrgica relativamente sencilla de realizar, que provee de una adecuada visibilidad al campo operatorio, permite evaluar y tratar con mayor facilidad las fracturas de esta zona y que su curso postquirúrgico no presenta complicaciones. Además, el resultado estético es óptimo, ya que

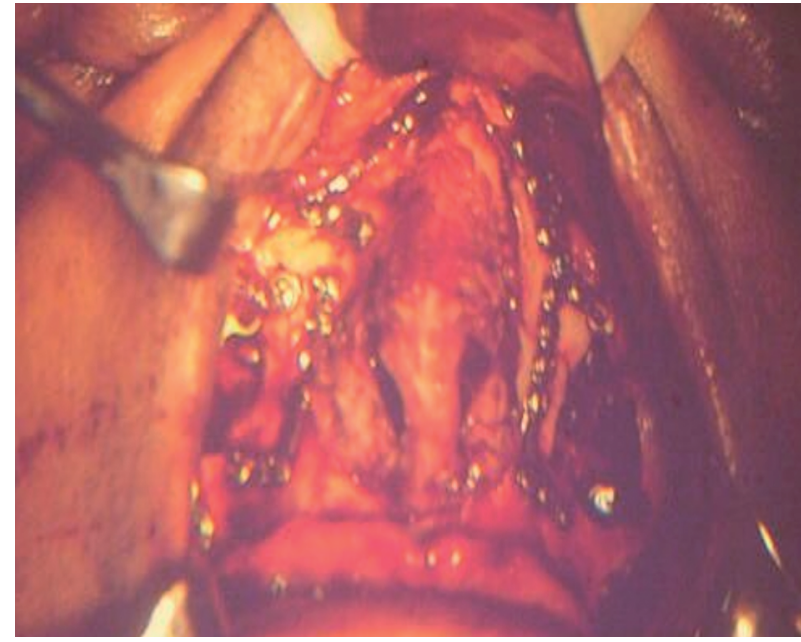

Figura 5. Fijación de las fracturas.

Figure 5. Fracture fixation.



Figura 6. Vista postquirúrgica de frente Figure 6. Frontal postoperative view. that resolved slowly and correct healing of the approach incisions, without the development of hematoma or stenosis of the nasal vestibule. Intermaxillary fixation was maintained for 8 weeks, coursing during this period of immobilization without complications and with stable occlusion. After removal of the intermaxillary fixation, no occlusion abnormalities were observed. The spatial relations of the patient's face were restored by the surgical treatment (Fig. 6). Follow-up radiographs showed the fracture zones with properly positioned miniplates and confirmed the restoration of the anteroposterior, sagittal, and transverse relations of the midface (Fig. 7).

\section{Discussion}

Ample bibliography exists on the use of midfacial degloving as a surgical approach for the treatment of superficial benign and malignant sinonasal pathology. ${ }^{1-9}$

In 1992, the application of the technique to facial trauma was cited, but it was not until 2001 that Baumann and Ewers 5 first reported in the maxillofacial literature their experience with the use of the technique in 14 patients with midfacial trauma. They obtained good results in relation to the surgical field exposure and the reduction of postoperative complications reported previously in the literature.

In this article, we report a case of severe facial trauma managed with midfacial degloving as an approach to the zone. The results obtained in the case confirmed that the technique is applicable and safe, and the patient's postoperative course was uneventful. The results of its application in this study are similar to those reported in the literature, confirming that it is a relatively simple surgical technique to 
no hay incisiones cutáneas. Se trata de una alternativa favorable principalmente en los pacientes jóvenes, ya que con esta técnica se evitan las secuelas estéticas por la presencia de las cicatrices cutáneas en el tercio medio de la cara.

\section{Conclusiones}

De acuerdo con los resultados del caso, el uso de disección del tercio medio facial como abordaje quirúrgico es útil en el tratamiento de fracturas del tercio medio facial, al proporcionar un amplio campo visual de la zona a intervenir y por tener una baja incidencia de complicaciones transquirúrgicas y postquirurgicas.

\section{Bibliografía}

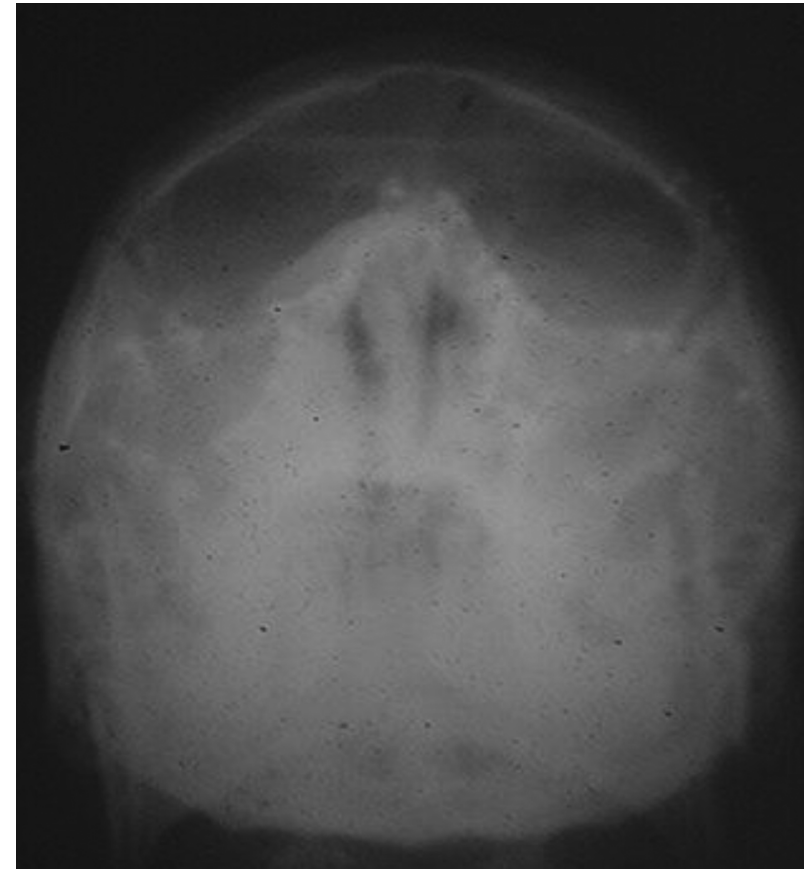

Figura 7. Radiografía Watters de control. Figure 7. Follow-up Watters radiograph. execute and that it provides adequate visibility of the operating field, and makes it easier to evaluate and treat midface fractures. The postoperative course was free of complications. The esthetic result also was optimal because there were no skin incisions. It is a good alternative, particularly in young patients, because the technique avoids disfiguring the midface with skin scars.

\section{Conclusions}

According to the results of the case, midfacial degloving was a useful surgical approach to midface fractures, providing an ample field of vision of the intervention area with a low incidence of transoperative and postoperative complications.

1. Casson PR y cols. The midface deglobing procedure. Plast Reconstr Surg 1974;53: 102-3.

2. Maniglia A. Indications and techniques of midfacial deglobing: a 15-year experience. Arch Otolaryngol Head Neck Surg 1986;112:750-2.

3. Holliday M. The versatile midface deglobing approach. Laryngoscope 1988; 98:291-5.

4. Romo T y cols. Repair of nasal septal perforation utilizing the midface deglobing technique. Arch Otolaryngol Head Neck Surg 1988;114:739-42.

5. Baumann A, Ewers R. Midfacial deblobing: an alternative approach for traumatic corrections in the midface. Int J Oral Maxillofac Surg 2001;30:272-77.

6. Dudley H y cols. Rob \& Smith's operative head and neck surgery. part II: Midfacial deglobing technique (sublabial approach) for nasal and paranasal sinus resection. Butterworth-Hewemann LTD 1992. Oxford UK.

7. Johns ME y cols. Atlas of head and neck surgery. vol. 1: Midfacial deglobing approach to the sinuses. B.C. Becker Inc. Philadelphia 1990.

8. Anand V, Coley J. Sublabial surgical approach to the nasal cavity and paranasal sinuses. Laryngoscope 1983;93:1483-84.

9. Paavolainen M. Sublabial approach to the nasal and paranasal cavities using nasal pyramid osteotomy and septal transection. Laryngoscope 1986;96:106-8.

10. Fonseca R y cols. Oral and Maxillofacial Trauma. Vol. 1 \& 22nd edition. W\&B Saunders Co 1997. 